Article

\title{
Exposure to Dodecamethylcyclohexasiloxane (D6) Affects the Antioxidant Response and Gene Expression of Procambarus clarkii
}

\author{
Md Muzammel Hossain ${ }^{1,2,3}$ (D), Yuan Yuan ${ }^{1}$, Hengliang Huang ${ }^{1}$, Ziwei Wang ${ }^{1}$, Mohammad Abdul Baki ${ }^{3}$, \\ Zhihua Dai ${ }^{1,4}$, Muhammad Rizwan ${ }^{1,5}$, Shuanglian Xiong ${ }^{1}$, Menghua Cao ${ }^{1}$ and Shuxin Tu ${ }^{1,2, *}$
}

check for

updates

Citation: Hossain, M.M.; Yuan, Y.; Huang, H.; Wang, Z.; Baki, M.A.; Dai, Z.; Rizwan, M.; Xiong, S.; Cao, M.; Tu, S. Exposure to

Dodecamethylcyclohexasiloxane (D6) Affects the Antioxidant Response and Gene Expression of Procambarus clarkii. Sustainability 2021, 13, 3495. https://doi.org/10.3390/su13063495

Academic Editors: Guijin Su and Tieyu Wang

Received: 17 February 2021

Accepted: 16 March 2021

Published: 22 March 2021

Publisher's Note: MDPI stays neutral with regard to jurisdictional claims in published maps and institutional affiliations.

Copyright: (c) 2021 by the authors. Licensee MDPI, Basel, Switzerland. This article is an open access article distributed under the terms and conditions of the Creative Commons Attribution (CC BY) license (https:// creativecommons.org/licenses/by/ $4.0 /)$.
1 College of Resources and Environment, Huazhong Agricultural University, Wuhan 430070, China; muzammel@webmail.hzau.edu.cn (M.M.H.); yuany@webmail.hzau.edu.cn (Y.Y.); hhl@webmail.hzau.edu.cn (H.H.); wangziwei@webmail.hzau.edu.cn (Z.W.); daizhihua@webmail.hzau.edu.cn (Z.D.); muhammadrizwan@webmail.hzau.edu.cn (M.R.); xsl@mail.hzau.edu.cn (S.X.); caomenghua@mail.hzau.edu.cn (M.C.)

2 Hubei Research Centre for Soil Remediation Engineering, Wuhan 430070, China

3 Department of Zoology, Faculty of Life and Earth Science, Jagannath University, Dhaka 1100, Bangladesh; mabaki@gmail.com

4 College of Environmental and Resource Sciences, Zhejiang University, Hangzhou 310058, China

5 Institute of Soil Science, PMAS-Arid Agriculture University, Rawalpindi 46000, Pakistan

* Correspondence: stu@mail.hzau.edu.cn; Tel.: +86-15802709291

\begin{abstract}
Dodecamethylcyclohexasiloxane (D6) is widely used daily in the chemical industry and exists in the environment; however, its eco-toxicity is not well documented. A hydroponic experiment was performed to investigate the effects of D6 exposure $\left(10-1000 \mathrm{mg} \mathrm{L}^{-1}\right)$ on oxidative stress induction and gene expression changes in crayfish (Procambarus clarkii). The results showed that superoxide dismutase (SOD) activity was enhanced by $20-32 \%$ at low D6 exposure $\left(10 \mathrm{mg} \mathrm{L}^{-1}\right)$ in muscle but reduced in gill tissue at high D6 exposure $\left(1000 \mathrm{mg} \mathrm{L}^{-1}\right)$. High D6 $\left(1000 \mathrm{mg} \mathrm{L}^{-1}\right)$ also increased catalase (CAT) and peroxidase (POD) activities in muscle tissue by $14-37 \%$ and $14-45 \%$, respectively, and the same trend was observed in the carapace and gill tissue of crayfish. The Malondialdehyde (MDA), ascorbate (AsA), and glutathione (GSH) contents were increased by $16-31 \%, 19-31 \%$, and $21-28 \%$ in the muscle of crayfish under D6 exposure. Additionally, silicon (Si) content increased in three organs (gill, carapace, and muscle) of crayfish. Related genes involved in enzyme and nonenzyme activities were detected, and when crayfish was exposed to D6, genes such as Sod3, Cat3, Pod3, and Gsh3 were up-regulated, while Asa3 and Oxido3 were significantly down-regulated in the muscle. The research results help us to understand the toxicity of D6 in crayfish and provide a basis for further research on the mechanism of D6-induced stress in crayfish and other aquatic organisms.
\end{abstract}

Keywords: silicone; D6; antioxidation; transcriptome; crayfish

\section{Introduction}

Silicone products are artificially manufactured in different forms, including liquids, solids, semiviscous pastes, greases, oils, and rubber, and are widely used in different industrial sectors such as construction, textiles, mechanical, carpeting, paper, architectural coatings, sealants, ink, paint, fluids and medical devices [1]. Dodecamethylcyclohexasiloxane (D6) is a cyclic volatile methylsiloxane colorless liquid with a molecular formula of $\mathrm{C}_{12} \mathrm{H}_{36} \mathrm{O}_{6} \mathrm{Si}_{6}$ [2]. It is mostly used as a raw material to produce silicone gel, rubber, and resin and assess environmental risks [3]. The US Environmental Production Agency and the Organization for Economic Co-Operation and Development (OECD) categorize D6 as a high production volume chemical [4-6]. Although America and Europe produce silicone, China is the biggest manufacturer and consumer of silicones and polysiloxanes 
in the world, with a yearly consumption of approximately 270,000 and 430,000 tons, respectively [7]. About 470,000 tons and 800,000 tons of silicone are produced annually in the US and China, respectively [8]. In 2002, the annual produced or imported amount of D6 was about USD 13 to 69 million in the United States [9]. It is estimated that the yearly growth rate of silicones is $6 \%$ due to the worldwide demand caused by the growing end-use market [10].

The mass utilization of D6 has resulted in excess D6 accumulation in the environment $[11,12]$. Industrial activity, sewage treatments, and landfills were found to increase D6 concentration in the environment $[13,14]$. About $90 \%$ of D6 is used in product materials for personal care [15,16], which then accumulate in the atmosphere, wastewater [17-20], and sediments in Nordic countries (Iceland, Finland, Sweden, Denmark, Norway, and the Faroe Islands) [21]. In addition, silicone can easily be mixed in agricultural water and soil due to its physicochemical properties, and it is considered a high priority for assessing ecological risk, bioaccumulation, human health, and inherent toxicity to aquatic organisms [22,23].

Exposure to silicone may have a harmful effect on organisms. Siloxane concentrations are minimal in aquatic animals. D6 concentration has been recorded in fish samples from Spanish supermarkets [24], rainbow trout fish [25], guppies (Poecilia reticulata), goldfish (Carassius auratus) [26], fathead minnows (Pimephales Promelas), and invertebrates (Daphnia magna) [27]. In a long-term study, the mortality rate of freshwater fish (fathead minnows) was shown to be $12 \%$ in the $4.4 \mu \mathrm{g} \mathrm{L}^{-1} \mathrm{D} 6$ treatment group [28]. The liver of mice and rats was also injured [29,30], and recently, Onnekink et al. [31] reported that cell death occurs in cultured cells due to D6 exposure.

However, D6 exposure in aquatic animals has rarely been studied for antioxidant response and gene expression. Crayfish (Procambarus clarkii) is recognized as a vulnerable species in the aquatic ecosystem [32]. Among invertebrates, this species is usually used as a test organism for biomonitoring studies due to its sensitivity to toxicity, importance in freshwater ecology, and high bioaccumulation ability in the environment [33]. D6 in agriculture through irrigated water, river water, and wastewater may have a harmful effect on crayfish. Thus, we hypothesize that D6 affects the antioxidant system, the production of reactive oxygen species, and breathing chain-related gene functions in the crayfish species. Thus, in this study, our objectives were to examine antioxidant enzyme activity and related gene expression in crayfish tissues under D6 stress.

\section{Materials and Methods}

\subsection{Resources for the Experiment}

In this experiment, crayfish (P. clarkii Girard, 1852) was cultured in an aqua black box with natural water (temperature: $22-23{ }^{\circ} \mathrm{C}, \mathrm{pH} 7.24 \pm 0.2$, electric conductivity: $375 \pm 1.4 \mu \mathrm{S} / \mathrm{cm}$, hardness: $\left.162.0 \pm 3.0 \mathrm{mg} \mathrm{L}^{-1}\right)$. Different doses of D6 were used as chemical stress in the culture water with crayfish.

\subsection{Experimental Procedure}

In the study, the hydroponic experiment was designed with crayfish and a total of 12 experiment black box $(47.0 \mathrm{~cm} \times 34.0 \mathrm{~cm} \times 15.5 \mathrm{~cm})$ ponds containing $3 \mathrm{~L}$ of dechlorinated natural water. Four treatments were designed as the control (CK), 10, 100, and $1000 \mathrm{mg} \mathrm{L}^{-1}$ D6. Then, freshwater crayfish were cultured in each experiment black box pond. Three replications were performed, and each treatment took six crayfish, and a total of 72 crayfish were encaged for the treatment. During the study period, the liquid silicone chemical D6 $\left(0,10,100\right.$, and $\left.1000 \mathrm{mg} \mathrm{L}^{-1}\right)$ was mixed with water in the experimental box pond. The photoperiod time was $12 \mathrm{~h}$ light and $12 \mathrm{~h}$ dark.

\subsection{Preparation of Samples and Analysis}

Adult crayfish samples were randomly harvested after $72 \mathrm{~h}$ and washed with pure water. During the sampling process, vessels and dissecting tools were washed with $\mathrm{HNO}_{3}$ (Merck Suprapur $^{\circledR}$ ) for the operation of crayfish and then bathed with deionized water 
(Milli-Q) to reduce the chance of contamination. The crayfish samples were anesthetized on ice for $15 \mathrm{~min}$, and $0.5 \mathrm{~g}$ carapace, $0.5 \mathrm{~g}$ gill, and $0.5 \mathrm{~g}$ muscle samples were collected. All samples for assay were stored at $-80^{\circ} \mathrm{C}$. The crayfish organ samples (gill, carapace, and muscle) were homogenized (1:10 $w / v)$ in an ice-cold buffer (50 mM Tris- $\mathrm{HCl} \mathrm{pH} \mathrm{7.4)} \mathrm{to}$ estimate the activities of SOD, POD, and CAT. To determine MDA, AsA, and GSH content, single organs (muscle) of crayfish were homogenized $(1: 10 w / v)$ in $5 \%$ trichloroacetic acid (TCA). After grinding, the solutions of all samples were shifted to a centrifugation tube $(10 \mathrm{~mL})$. Then, all homogenate samples were centrifuged (Model $5810 \mathrm{R}$ ) at 10,000 rpm for $15 \mathrm{~min}$ at $4{ }^{\circ} \mathrm{C}$. To determine enzyme and nonenzyme activities, all supernatant samples were collected and immediately preserved at $-20^{\circ} \mathrm{C}$. For $\mathrm{Si}$ determination, three organs (gill, carapace, and muscle) of crayfish were collected and dehydrated at $70{ }^{\circ} \mathrm{C}$ for $96 \mathrm{~h}$. The conical flax was washed with $95 \%$ alcohol and deionized water. The conical cover was rinsed by an ultrasonic cleaning machine with pure water $\left(5.57 \mu \mathrm{S} \mathrm{cm}^{-1}\right)$ for $5 \mathrm{~min}$, washed with deionized $\mathrm{H}_{2} \mathrm{O}$, and then dried at $45^{\circ} \mathrm{C}$ for $24 \mathrm{~h}$.

\subsection{Determination of Enzyme and Nonenzyme Activities}

The supernatants of crayfish organ samples (gill, carapace, and muscle) were used to determine SOD activity referring to the technique of Dhindsa et al. [34]. SOD activity was assayed as a $\mathrm{U} \mathrm{mg}^{-1}$ protein, where $\mathrm{U}$ was the inhibited photochemical reduction of nitroblue tetrazolium (NBT), and the absorbance was recorded at $560 \mathrm{~nm}$. CAT activity was monitored by the disappearance of $\mathrm{H}_{2} \mathrm{O}_{2}$ at $\triangle \mathrm{OD} 240$ protocols following the method of Aebi [35]. POD activity was exhibited by a $\mathrm{U} \mathrm{mg}^{-1}$ protein, where $1 \mathrm{U}$ was assayed as $\triangle O D 470 \mathrm{~min}^{-1}$ according to Huang et al. [36]. The amount of MDA for estimating the lipid peroxidation was according to the method of Heath and Packer [37] and assayed on 96-well plates as $\triangle \mathrm{OD} 532, \triangle \mathrm{OD} 600$, and $\triangle \mathrm{OD} 450$. MDA content was recorded as $\mu \mathrm{mol} \mathrm{g}^{-1}$ fresh weight (FW). AsA content was measured as mg AsA g ${ }^{-1} \mathrm{FW}$ and defined as $\Delta$ OD525 by the spectrophotometer technique of Guo et al. [38]. GSH content was reported as $\mathrm{mg} \mathrm{g}^{-1}$ FW and estimated by the absorption of a spectrophotometer at $412 \mathrm{~nm}$ within $30 \mathrm{~s}$ of response followed the method of Han et al. [39].

\subsection{Determination of Si Content}

Three organs (muscles, gill, and carapace) of crayfish tissue samples were digested and assayed by the method of Huang et al. [40]. Concisely, $0.2 \mathrm{~g}$ of dry tissue was weighed and saturated in $10 \mathrm{~mL}$ of mixed solution $\left(\mathrm{HNO}_{3}: \mathrm{HClO}_{4}=9: 1, v / v\right)$ in Teflon beakers for $12 \mathrm{~h}$ (overnight), and $5 \mathrm{~mL}$ of $\mathrm{H}_{2} \mathrm{O}_{2}$ was added when the solutions became reddish-brown. Then, on the hotplate compartment (Lab Tech EH35B), the mixed solution was heated at $180{ }^{\circ} \mathrm{C}$ until the volume reached 1 or $2 \mathrm{~mL}$. A $15 \mathrm{~mL}$ volume of DI water was added after the solutions showed colloidal precipitate, and then the solution became sunlit yellow. A $3 \mathrm{~mL}$ volume of $50 \% \mathrm{NaOH}$ solution was added in the solution and covered for $60 \mathrm{~min}$ at $180^{\circ} \mathrm{C}$. Then, the solution was shifted to a sample container and made up to $25.0 \mathrm{~g}$ after refrigerating at room temperature. At last, the colorimetric molybdenum blue technique method followed to measure the Si content.

\section{6. $R N A$ Isolation, Preparation, and $q R T-P C R$}

After treating with D6, crayfish muscle samples were collected according to the manufacturer's procedures using a Tri reagent to extract total RNA for the analysis of RNA-seq. RNA Nano 6000 Assay Kit (Agilent Technologies, Santa Clara, CA, USA) was used to evaluate the RNA. Unigene's SSR and primers were verified for each SSR [41]. Unigene was confirmed by MISA (v1.0), and the primer design was completed with Primer3 (version 2.2.2) [42]. All primer sets for the genes are noted in Table S1 (Supplementary Materials). The mRNA was supported to build the cDNA library that was collected from the treated samples. The relative abundance of mRNA was determined by the method of RT-qPCR. The NanoDrop ${ }^{T M} 2000$ UV spectrophotometer was used to quantify the RNA (Thermo-Scientific, Waltham, MA, USA). We verified the RT-PCR product quality by 
electrophoresis on $1.5 \%$ agar gel. qRT-PCR was led in a $20 \mu \mathrm{L}$ reaction volume covered with $10 \mu \mathrm{L}$ of $2 \times$ SybrGreen qPCR Master Mix, $2 \mu \mathrm{L}$ of cDNA, $0.4 \mu \mathrm{L}$ of reverse and forward primers, and $7.2 \mu \mathrm{LddH} \mathrm{H}_{2} \mathrm{O}$. The conditions of $95^{\circ} \mathrm{C}$ for $3 \mathrm{~min}, 45$ cycles at $95{ }^{\circ} \mathrm{C}$ for $3 \mathrm{~s}$, and $60{ }^{\circ} \mathrm{C}$ for $30 \mathrm{~s}$ followed for the PCR amplification. Target genes of specific primers are listed in Table S1 (Supplementary Materials). According to the $2^{-\triangle \Delta C t}$ method, the relative genes were analyzed [43]. The RNA-seq data quality was perfect and reliably evaluated via qRT-PCR analysis.

\subsection{Data Analysis}

Experimental data were analyzed using STAR (version 2.0.1) with R language [44]. STAR is a statistical computing and graphics software developed by IRRI. Independent three replicates $(n=3)$ data were performed for each treatment. Data were normally distributed and tested by the Shapiro-Wilk test. The groups' differences were estimated by a one-way ANOVA test, LSD test, and DMRT test. Statistical significance at the $p<0.05$ level was indicated by different small letters. Graphs were developed by Microsoft Excel 2016, Sigmaplot version 12.0, and Microsoft Power Point 2016.

\section{Results}

\subsection{Effect of $D 6$ on the Activity of Antioxidant Enzymes}

SOD, CAT, and POD activities in different organs (gill, carapace, and muscle) of crayfish under D6 stress in this study are shown in Figure 1. All the antioxidant enzymes contributed to the enzyme regulation system and related to the active oxygen species scavengers.

\subsubsection{Superoxide Dismutase (SOD) Activity}

In comparison with the control (CK), D6 exposure in crayfish significantly $(p<0.05)$ improved SOD activity in tissue samples by $17-38 \%$ in carapace, $26-30 \%$ in gill, and $20-32 \%$ in muscle at a low concentration $\left(10 \mathrm{mg} \mathrm{L}^{-1}\right)$, while at a high concentration level (1000 $\left.\mathrm{mg} \mathrm{L}^{-1}\right)$, it decreased by $38-21 \%$ in carapace, $30-17 \%$ in gill, and $32-21 \%$ in muscle, respectively, as shown in Figure 1A. The average ranges of SOD activity were $61.46 \pm 4.54$ to $109.18 \pm 5.71 \mathrm{U} \mathrm{g}^{-1} \mathrm{FW}$ in gill, $33.07 \pm 3.017$ to $71.41 \pm 2.09 \mathrm{U} \mathrm{g}^{-1} \mathrm{FW}$ in carapace, and $40.48 \pm 1.37$ to $64.55 \pm 5.02 \mathrm{U} \mathrm{g}^{-1} \mathrm{FW}$ in muscle samples, respectively. The trend of the highest SOD activity in the three tissues can be expressed as gill $>$ carapace $>$ muscle.

\subsubsection{Peroxidase (POD) Activity}

The highest POD activity was found at the maximum concentration level $\left(1000 \mathrm{mg} \mathrm{L}^{-1}\right)$ of D6 in gill, carapace, and muscle tissue, as shown in Figure 1B. The POD activity increased by $10-49 \%$ in carapace, $9-52 \%$ in gill, and $14-45 \%$ in muscle, respectively, and the POD activity trend can be expressed as gill $>$ carapace $>$ muscle for D6 treatment. The average ranges of POD activity were $1.17 \pm 0.09$ to $6.90 \pm 0.47 \mathrm{U} \mathrm{g}^{-1} \mathrm{~min}^{-1} \mathrm{FW}$ in gill, $0.55 \pm 0.05$ to $2.83 \pm 0.31 \mathrm{U} \mathrm{g}^{-1} \mathrm{~min}^{-1} \mathrm{FW}$ in carapace, and $0.58 \pm 0.07$ to $1.92 \pm 0.26 \mathrm{U} \mathrm{g}^{-1} \mathrm{~min}^{-1}$ FW in muscle samples, respectively.

\subsubsection{Catalase (CAT) Activity}

Changes in CAT activity with different D6 concentration levels followed a similar trend to that observed in POD, and the maximum CAT activity was shown at high concentration levels (1000 $\mathrm{mg} \mathrm{L}^{-1}$ ) of D6 (Figure 1C). Compared with CK, CAT activity was improved significantly $(p<0.05)$ in the three organ samples of gill, carapace, and muscle by $8-34 \%, 9-35 \%$, and $14-37 \%$, respectively. Due to D6 stress, the CAT activity in the organ samples followed a downward trend in the order muscle $>$ gill $>$ carapace. The average CAT activity ranges were $0.02 \pm 0.0003$ to $0.07 \pm 0.005 \mathrm{U} \mathrm{g}^{-1} \mathrm{~min}^{-1} \mathrm{FW}$ in carapace samples, $0.02 \pm 0.0002$ to $0.09 \pm 0.003 \mathrm{U} \mathrm{g}^{-1} \mathrm{~min}^{-1} \mathrm{FW}$ in gill samples, and $0.08 \pm 0.006$ to $0.22 \pm 0.03 \mathrm{U} \mathrm{g}^{-1} \mathrm{~min}^{-1} \mathrm{FW}$ in muscle samples, respectively. 

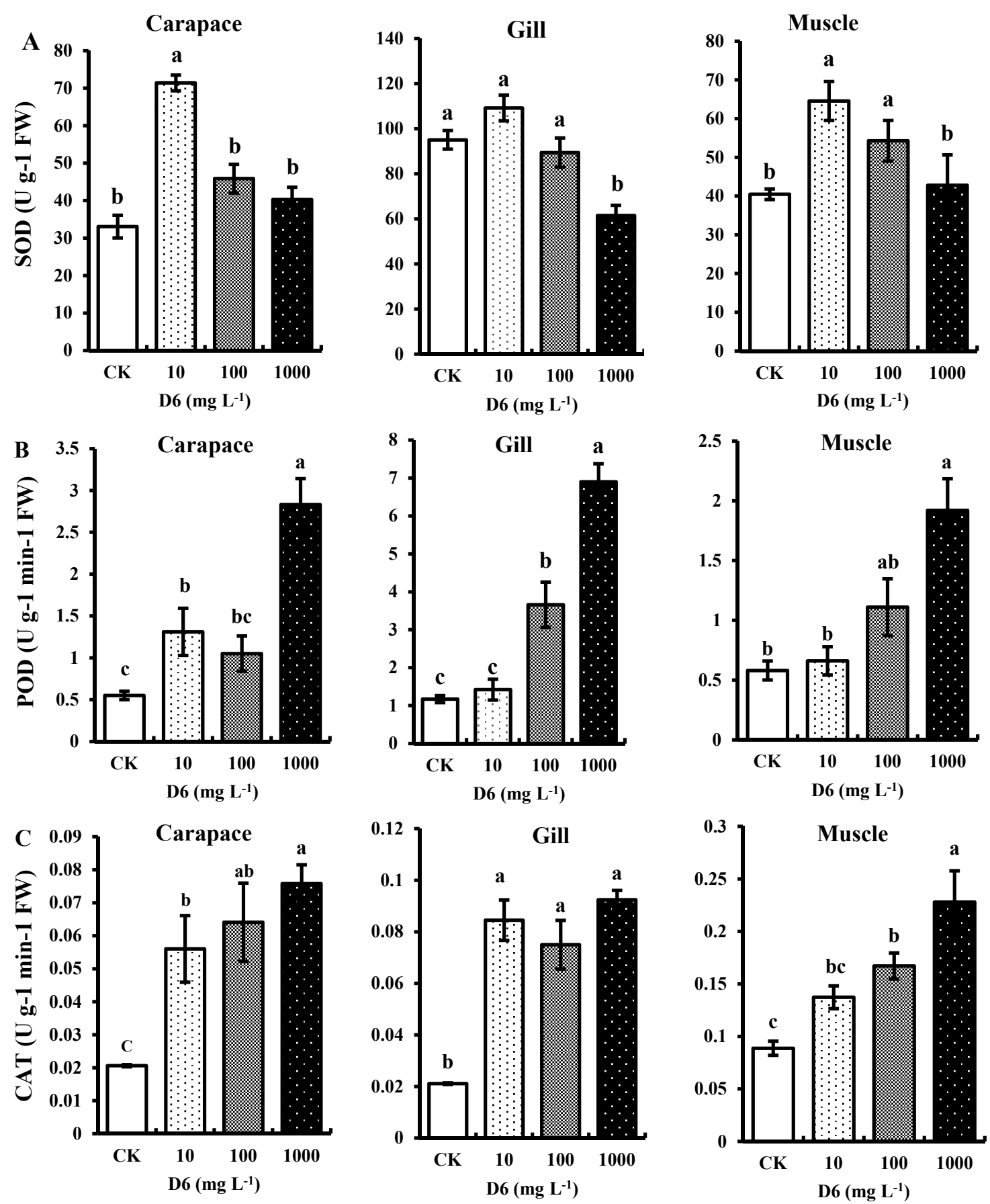

Figure 1. Estimated antioxidant enzymes: (A) superoxide dismutase (SOD), (B) peroxidase (POD), and (C) catalase (CAT) activities in the carapace, gill, and muscle tissue of crayfish under D6 $\left(\mathrm{mg} \mathrm{L}^{-1}\right)$ treatment. Bars denote SD for the means $(n=3)$. Different small letters show significant differences among the treatments at $p<0.05$.

\subsection{Effect of $D 6$ on the Non-Enzymatic Antioxidant \\ 3.2.1. Determination of Malondialdehyde (MDA) Content}

In crayfish muscle, MDA content was increased significantly $(p<0.05)$ by $16-31 \%$ under the treatment of D6, indicating toxicity in crayfish (Figure 2). Compared with CK, the highest MDA content level after D6 treatment was found 0.33-fold higher than those of the control. 

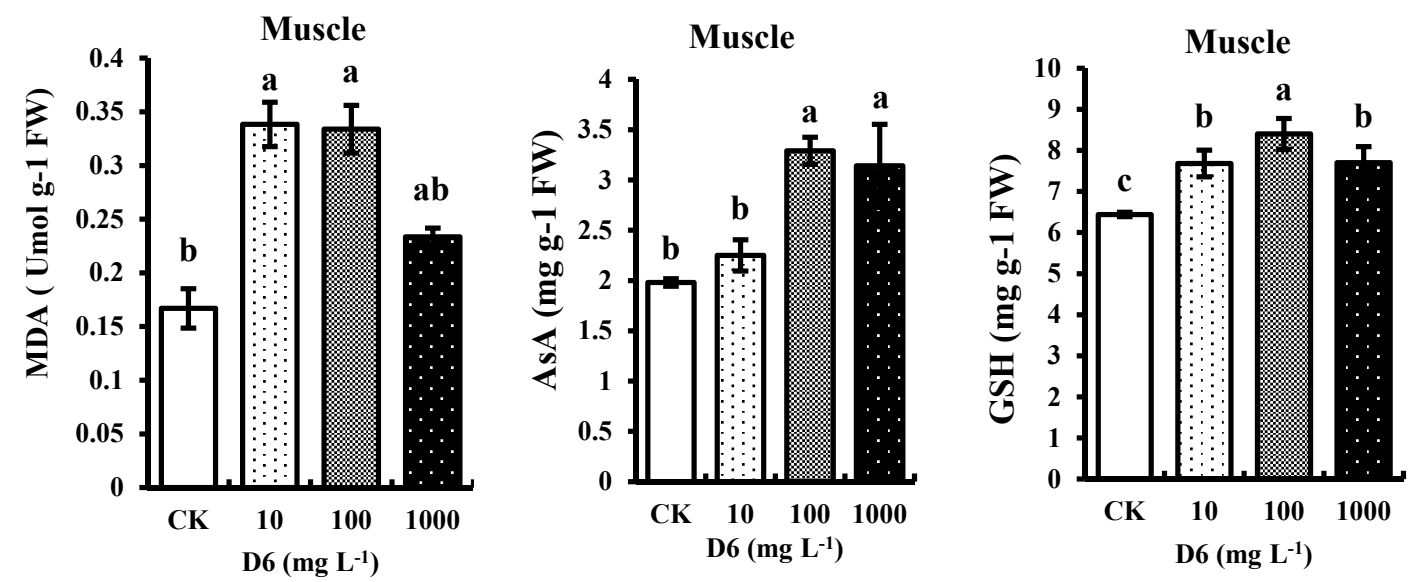

Figure 2. Estimated contents malondialdehyde (MDA), ascorbate (AsA), and glutathione (GSH) in the abdominal muscle of crayfish under different concentration levels of D6 $\left(\mathrm{mg} \mathrm{L}^{-1}\right)$ stress. Bars represent SD for the means $(n=3)$. Different small letters represent significant differences among the treatments at $p<0.05$.

\subsubsection{Determination of Ascorbate (AsA) and Glutathione (GSH) Contents}

Compared with CK, the nonenzymatic AsA and GSH contents were significantly $(p<0.05)$ improved with the increase of D6 concentrations, as presented in Figure 2. AsA and GSH contents were increased by $19-31 \%$ and $21-28 \%$ in muscle tissue. AsA and GSH contents at $100 \mathrm{mg} \mathrm{L}^{-1} \mathrm{D} 6$ exposure were a maximum of 3.29-fold and 8.4-fold higher than the control.

\subsection{Silicon (Si) Content and Survival Rate of Crayfish}

Si content was estimated in the different organs (gill, carapace, and muscle) of crayfish after treatment with D6 (Figure 3). Compared with CK, the highest Si content was found in the muscle tissue of crayfish and the organ of crayfish Si content followed a downward trend in the order muscle $>$ gill $>$ carapace. Si content was $2.98 \pm 0.08 \mathrm{~g} \mathrm{~kg}^{-1}$ in muscle tissue, $0.47 \pm 0.05 \mathrm{~g} \mathrm{~kg}^{-1}$ in gill tissue, and $0.04 \pm 0.007 \mathrm{~g} \mathrm{~kg}^{-1}$ in carapace tissue, respectively.
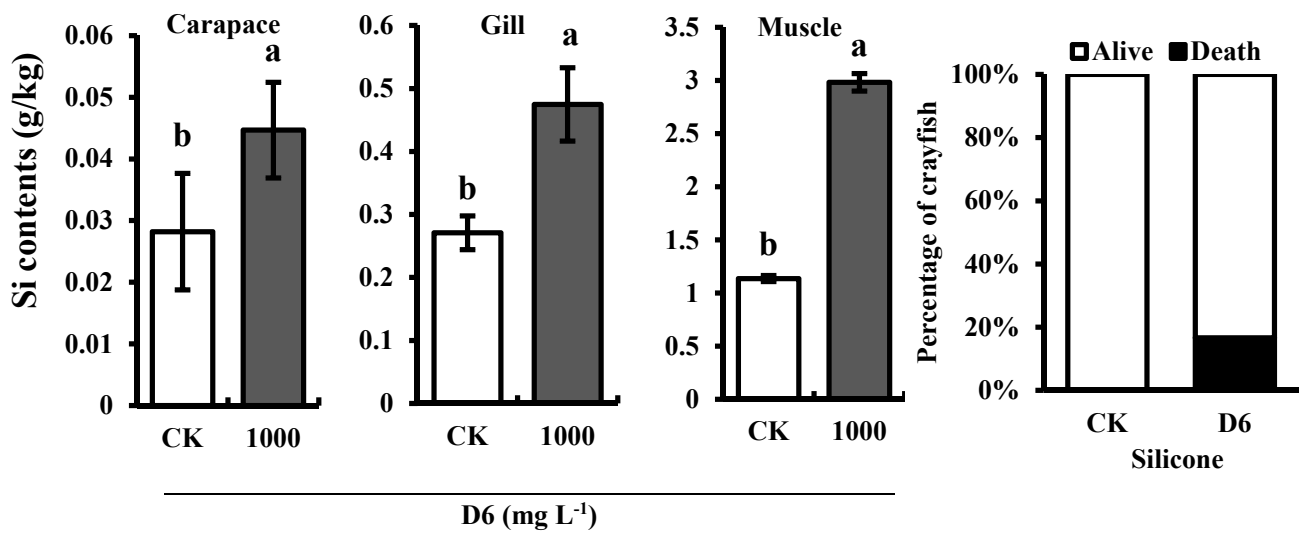

D6 $\left(\mathrm{mg} \mathrm{L}^{-1}\right)$

Figure 3. Estimated Si contents in the different organs (carapace, gill, and muscle) of crayfish and the percentage (\%) of dead and alive crayfish treated with D6.

Increasing the concentration of D6 decreased the survival rate due to the loss of crayfish. In this experiment, $17 \%$ of dead crayfish were found, whereas all crayfish were alive in the control treatment, as shown in Figure 3. 


\subsection{Effects of D6 on Gene Expression in Muscle}

In this study, qRT-PCR was analyzed for the relative gene expression of antioxidant systems, which determined mRNA for target gene expression in the muscle tissue of crayfish. After treatment with different levels of D6, genes related to enzymatic and nonenzymatic activities were expressed as a molecular function of crayfish muscle.

The FPKM values of genes were verified, which was in charge of the individual gene expression under D6 stress. The gene expression level of each sample was different, and the identified gene results were significantly different in the muscles of crayfish $(p<0.05)$. We identified six genes related to antioxidant and nonenzyme activities in crayfish abdominal muscles treated with D6, as shown in Figure 4. Among all genes, individual Sod3, Cat3, Pod3, AsA3, Gsh3, and Oxido3 genes were expressed significantly $(p<0.05)$. The relative expression of Sod3 was higher at the low D6 concentration $\left(10 \mathrm{mg} \mathrm{L}^{-1}\right)$ than that of the high D6 level $\left(1000 \mathrm{mg} \mathrm{L}^{-1}\right)$. The relative expression of Sod3 was in charge of superoxide dismutase activity and its metabolic process, and the ion-binding activity was significantly amplified 4.06-fold with $10 \mathrm{mg} \mathrm{L}^{-1} \mathrm{D} 6$ treatment compared with CK. The relative expression of Cat3 was responsible for hydrolase activity and catalytic activity in the muscle of crayfish.
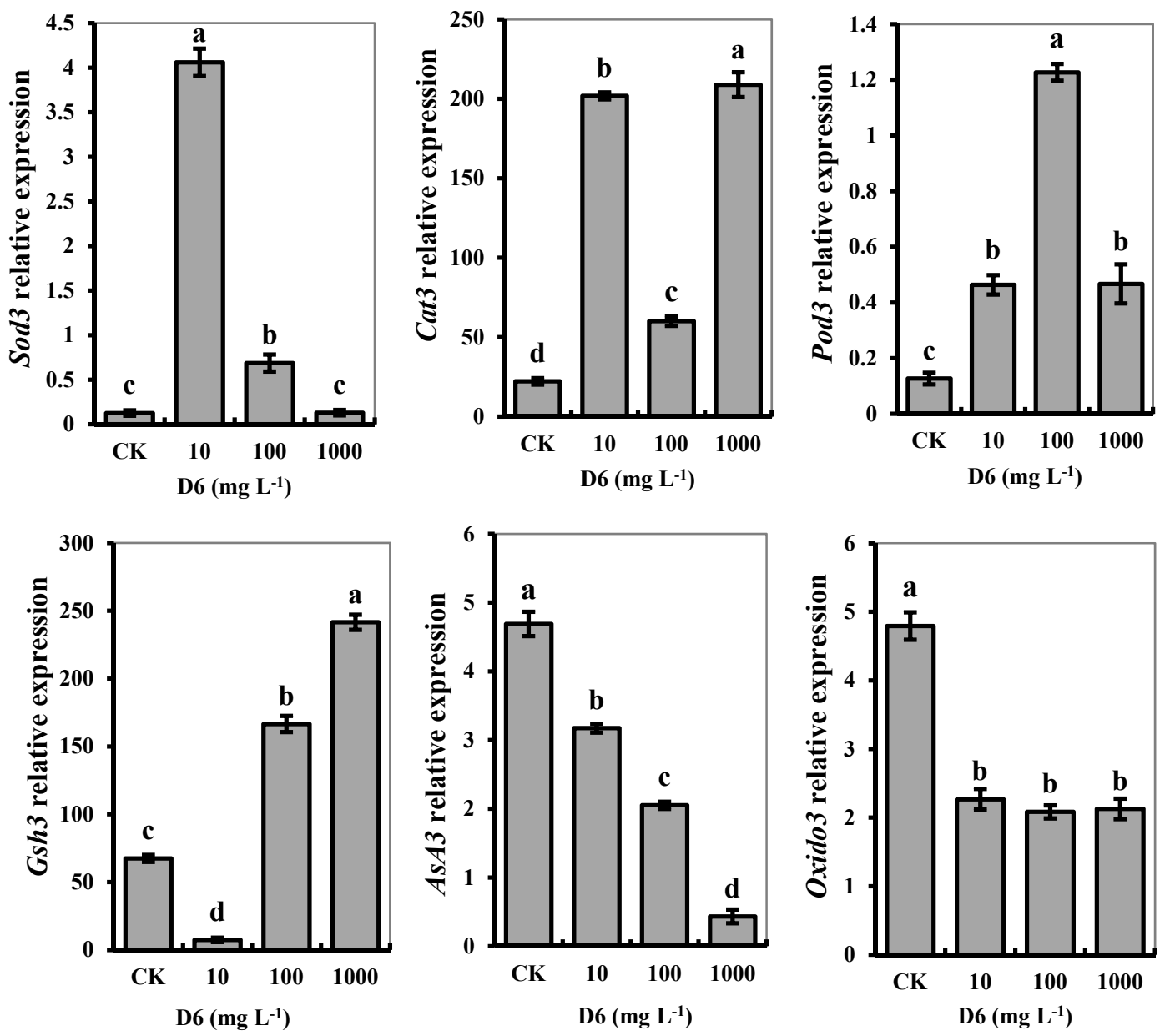

Figure 4. Effects of D6 on the relative gene expression of Sod3, Cat3, Pod3, AsA3, Gsh3, and Oxido3 in the muscle tissue of crayfish treated at different levels of D6. Different small letters represent significant differences among the treatments at $p<0.05$.

Compared with $\mathrm{CK}$, the relative expression of Cat3 was at its maximum at a D6 concentration of $10 \mathrm{mg} \mathrm{L}^{-1}$ and $1000 \mathrm{mg} \mathrm{L}^{-1}$, whereas Pod3 was highly expressed at a D6 concentration of $100 \mathrm{mg} \mathrm{L}^{-1}$. The relative expression of Pod3 was upregulated and responsible for cell adhesion, response to binding, oxidative stress, and peroxidase activity 
in the muscle tissue. The relative expression of Gsh3 related to nonenzymatic GSH content was highly expressed as upregulated, whereas the relative expression of Sod3, Cat3, and Pod3 was upregulated. The relative expression of Gsh 3 was in charge of glutamate-ammonia ligase activity, the process of nitrogen compound and glutamine biosynthesis, and the necessity of ATP in the muscle. The relative expression of Asa3 and Oxido3 related to AsA content and oxidoreductase activities and expression was downregulated. The relative expression of $A s a 3$ was responsible for glutathione transferase activity and dehydrogenase (ascorbate) activity in crayfish muscle tissue.

\section{Discussion}

We investigated enzyme and nonenzyme activities in crayfish tissues and analyzed the relative expression of the genes in muscle tissue after D6 treatment. The research aimed to verify how the crustaceans at biochemical, physiological, and molecular stages respond to various levels of D6.

With D6 treatment, SOD activity was decreased, while POD and CAT activities were increased, as shown in Figure 5. After the biochemical assay, MDA content was increased due to D6 exposure in muscle tissue, as shown in Figure 2, which has been recognized as toxicity and led to oxidative cell damage. Some studies have also reported MDA content was improved in crustacean species due to water pollution by industrial chemicals [45]. Increased MDA content has occurred in crayfish with silicone stress by way of a signal for the risk of tissue damage, resulting in crayfish mortality [46-48]. Oxidized lipid breakdown occurred through a large MDA content, which can play a role in the proteins. Carbonyl proteins perform through subordinate functions that cause free radical reactions by lipids $[49,50]$. In gill tissues, cell damage can affect gill function or metabolic rate and reduce the ability of ATP, which obstructs the role of the respiratory system in crayfish.

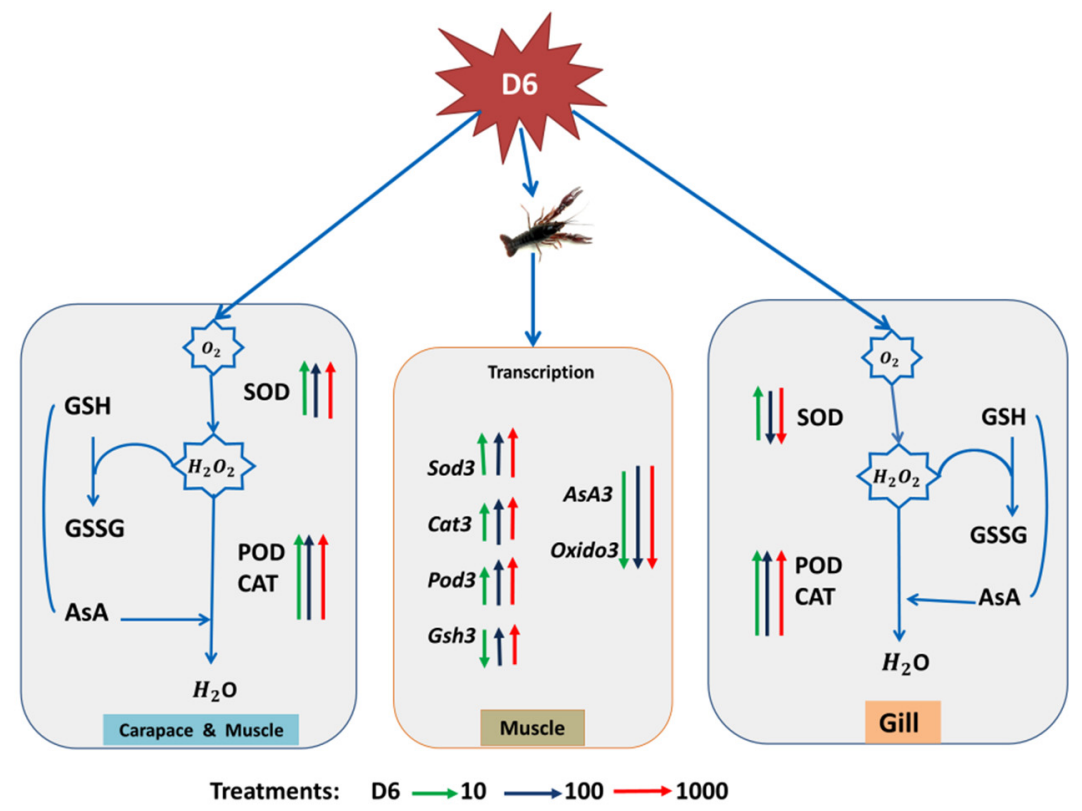

Figure 5. A proposed primary model for showing the effect of D6 $\left(\mathrm{mg} \mathrm{L}^{-1}\right)$ in the different organs of crayfish. The green, blue, and red arrows pointing upward represent an improved factor, and the arrows pointing downward represent a reduced factor.

Oxidative stress imbalances ROS production and antioxidant defenses, which leads to damaged organs or organisms in the aquatic toxicology [51]. Lipid peroxidation is considered a major pathway to indicate damage in various tissues. Biomolecules may be extremely deleterious and connected due to ROS-induced oxidative damage [52]. A different organ of crayfish exposed to D6 and ROS, especially superoxide and $\mathrm{H}_{2} \mathrm{O}_{2}$, was 
produced, which may influence protection by regulating the activities of SOD and CAT [53]. In this study, compared with CK, the highest activities of SOD and CAT were assessed in the organs (gill and muscle), as shown in Figure 1. SOD activity may provide support as protection against active oxygen species. Change of CAT activity in the organs (carapace, gill, and muscle) of crayfish indicated higher peroxide concentrations [54]. SOD and CAT activities may treat superoxide anions and $\mathrm{H}_{2} \mathrm{O}_{2}$, which is established as the first protection route against oxidative stress $[55,56]$.

Some studies also found similar activities of SOD and CAT in the organs of P. clarkii, A. leptodactylus, and A. astacus $[46,57,58]$. In three organs (gill, carapace, and muscle) of crayfish, POD activity was increased significantly $(p<0.05)$ after D6 exposure. SOD and POD are essential enzymes supporting the clear superoxide radicals and stopping damage to cells in various organs and tissue [59]. In crustacean species, SOD activity can play a vital immune role when crayfish are infected from stress, such as tiger prawn species [60], and POD can also act as an index enzyme to evaluate the immune function of crustaceans [61]. In the glutathione-ascorbate cycle of nonenzymatic agents, GSH and AsA contents were significantly $(p<0.05)$ increased in the muscle organ, which supported the antioxidant defense and decreased the damage of reactive oxygen species.

Authors also found similar results of GSH content in crustacean species of A. leptodactylus [62]. Increased GSH contents in aquatic organisms indicate the function regulated for protection [63]. Recently, transcriptome has become a very useful tool. Gene expression variance encodes proteins of antioxidants to evaluate the biological toxicity or the effects of pollutants [64,65]. Different numbers of genes are associated with the response of oxidative stress and are recognized in the muscle tissue of red swamp crayfish, as discussed in similar studies on zebra fish $[66,67]$. ROS levels were increased due to oxidative stress by D6. This study also detected relative expression genes of oxidoreductase activity after $1000 \mathrm{mg} \mathrm{L}^{-1}$ D6 exposure in crayfish, as shown in Figure 4. Electrons are transferred from the reductant to the oxidant that is maintained by the oxidoreductase enzyme catalase. Trans-2-enoylCoA and NADPH transpired in the muscle. The relative expression of Oxido3 is responsible for oxidoreductase activity as it is downregulated in the muscle of crayfish under D6 treatment. Superoxide dismutase, ion binding, and 2-hydroxyglutarate dehydrogenase activity are actively regulated through downregulated encoding genes. During protection, $\mathrm{NADH}$ or NAD+ and NADPH or NADP+ are active by enabling oxidative stress and the stability of GSH redox in crayfish [68]. Exposure to heavy metals in crustacean species also expresses redox- and detoxification-related genes [69]. Zhang et al. [70] also exhibited crayfish exposed to heavy metal, and the expressions of related genes were changed in the oxidation and reduction system in the immune function of crayfish.

\section{Conclusions}

In this study, D6 exposure significantly altered SOD, CAT, and POD activity in carapace, gill, and muscle tissue samples. MDA, GSH, and AsA contents were increased in the muscle tissues, suggesting that D6 exposure in crayfish promotes a stress response. Furthermore, enzyme-activity-related genes (Sod3, Cat3, and Pod3) were performed by upregulation, while nonenzyme related genes (AsA3 and Oxido3) were activated by downregulation. Furthermore, more Si content was accumulated in crayfish tissue when treated with D6. These findings reveal the effect of D6 on enzyme activity and related gene expression of crayfish and hint at the possible impact of silicone on lobsters and other aquatic organisms.

Supplementary Materials: The following are available online at https:/ / www.mdpi.com/2071-105 0/13/6/3495/s1, Table S1: Primer sequence list to determine mRNA for target genes expression in abdominal muscle of crayfish.

Author Contributions: For this research Investigation, Visualization, Resources, Data curation, Formal Analysis, Writing-original draft, M.M.H.; Investigation, review and editing, H.H.; Investigation, Resources, Y.Y.; Resources, review and editing, Z.D.; Review and editing, M.A.B.; Resources, Z.W.; 
Review and editing, M.R.; Review and editing, M.C.; Review and editing, S.X.; Conceptualization, Supervision, Funding acquisition, Project direction, Writing, review and editing, S.T. All authors have read and agreed for the publication. All authors have read and agreed to the published version of the manuscript.

Funding: National Key Research and Development Program (2018YFC1800305), Hubei Special Project for Technique Innovation (2017ABA154), and Guangxi Major Special Project of Science and Technique (AA17202026-3) supported this research.

Institutional Review Board Statement: Not applicable.

Informed Consent Statement: Not applicable.

Data Availability Statement: The data reported statistically in this study and data will be available on request from the corresponding author.

Conflicts of Interest: The authors declare no conflict of interest.

\section{References}

1. Will, R.; Löchner, U.; Masahiro, Y. CEH Marketing Research Report Siloxanes; SRI Consulting: Menlo Park, CA, USA, 2007.

2. Rücker, C.; Kümmerer, K. Environmental Chemistry of Organosiloxanes. Chem. Rev. 2015, 115, 466-524. [CrossRef] [PubMed]

3. Wang, D.-G.; Norwood, W.; Alaee, M.; Byer, J.D.; Brimble, S. Review of recent advances in research on the toxicity, detection, occurrence and fate of cyclic volatile methyl siloxanes in the environment. Chemosphere 2013, 93, 711-725. [CrossRef]

4. USEPA (United States Environmental Protection Agency). High Production Volume (HPV) Challenge Program. Sponsored Chemicals. Available online: http:/ / www.epa.gov/hpv/pubs/update/spnchems.htm (accessed on 1 September 2007).

5. OECD (Organisation for Economic Co-operation and Development). Manual for Investigation of HPV Chemicals. OECD Secretariat. Available online: http://www.oecd.org/document/7/0,3343,en_2649_34379_1947463_1_1_1_1,00.html (accessed on 1 July 2007).

6. Dudzina, T.; von Goetz, N.; Bogdal, C.; Biesterbos, J.W.; Hungerbühler, K. Concentrations of cyclic volatile methylsiloxanes in European cosmetics and personal care products: Prerequisite for human and environmental exposure assessment. Environ. Int. 2014, 62, 86-94. [CrossRef] [PubMed]

7. Wang, D.G.; Steer, H.; Tait, T.; Williams, Z.; Pacepavicius, G.; Young, T.; Ng, T.; Smyth, S.A.; Kinsman, L.; Alaee, M. Concentration of cyclic volatile methylsiloxanes in bio-solid amended soil, influent, effluent, receiving water, and sediment of wastewater treatment plants in Canada. Chemosphere 2013, 93, 766-773. [CrossRef]

8. Mojsiewicz-Pienkowska, K.; Krenczkowska, D. Evolution of consciousness of exposure to siloxanes-Review of publications. Chemosphere 2018, 191, 204-221. [CrossRef] [PubMed]

9. USEPA. Non-Confidential Inventory Update Reporting Production Volume Information. Toxic Substances Control Act (TSCA) Inventory. Available online: http:/ / www.epa.gov/oppt/iur/tools/data/2002-vol.htm (accessed on 16 March 2021).

10. De Arespacochaga, N.; Valderrama, C.; Raich-Montiu, J.; Crest, M.; Mehta, S.C.; Cortina, J. Understanding the effects of the origin, occurrence, monitoring, control, fate and removal of siloxanes on the energetic valorization of sewage biogas-A review. Renew. Sustain. Energy Rev. 2015, 52, 366-381. [CrossRef]

11. PMRA (Pest Management Regulatory Agency). Regulatory Note REG 2007-04: PMRA List of Formulants Ottawa (ON): Health Canada, Pest Management Regulatory Agency. Available online: http://www.pmra-arla.gc.ca/english/pdf/reg/reg2007-04-e. pdf (accessed on 1 July 2007).

12. DPD (Drug Product Database). Ottawa (ON): Health Canada. 2007. Available online: http://www.hc-sc.gc.ca/dhp-mps/ prodpharma/databasdon/index_e.html (accessed on 1 July 2007).

13. Norden. Siloxanes in the Nordic Environment. TemaNord 2005, 593. Copenhagen (NO), Nordic Council of Ministers. Available online: http:/ / www.norden.org/pub/miljo/miljo/uk/TN2005593.pdf (accessed on 16 March 2021).

14. Kaj, L.; Andersson, J.; Palm Cousins, A.; Remberger, M.; Ekheden, Y.; Dusan, B.; Bror-ström-Lundén, E. Results from the Swedish National Screening Programme 2004: Subreport 4: Siloxanes, IVL. Swedish Environmental Research Institute. Available online: www.imm.ki.se/Datavard/PDF/B1643_siloxaner.pdf (accessed on 16 March 2021).

15. Zhang, K.; Wong, J.W.; Begley, T.H.; Hayward, D.G.; Limm, W. Determination of siloxanes in silicone products and potential migration to milk, formula and liquid simulants. Food Addit. Contam. Part A 2012, 29, 1311-1321. [CrossRef] [PubMed]

16. Horii, Y.; Kannan, K. Survey of Organosilicone Compounds, Including Cyclic and Linear Siloxanes, in Personal-Care and Household Products. Arch. Environ. Contam. Toxicol. 2008, 55, 701-710. [CrossRef]

17. Lucas, S.V.; Kopfler, F.C. GC/MS Analysis of Organics in Drinking Water Concentrates and Advanced Waste Treatment Concentrates. U.S. Environmental Protection Agency, Office of Research and Development, Health Effects Research Laboratory.Volume 1, EPA 600/1-84-020a; EPA 600/1-84-020b; EPA 600/1-84-020c; EPA-68-03-2548; PB85128221. Available online: https: / / nepis.epa.gov / Exe/ZyPDF.cgi?Dockey=9100A600.PDF (accessed on 16 March 2021).

18. USEPA. Thirtieth Report of the Interagency Testing Committee to the Adminstrator, Receipt of Report and Request for Comments Regarding Priority Testing List of Chemicals; Federal Register, EPA: Washington, DC, USA, 1992; Volume 57. 
19. Allen, R.B.; Kochs, P.; Chandra, G. Industrial Organic Materials, Their Environmental Entry and Predicted Fate. In Organosilicon Materials; Hutzinger, O., Ed.; Part of the Handbook of Environmental Chemistry; Springer: Berlin/Heidelberg, Germany, 1997; pp. 1-25. [CrossRef]

20. Flynn, K.; Spellman, T. Environmental levels of atrazine decrease spatial aggregation in the fresh water mussel, Elliptio complanata. Ecotoxicol. Environ. Saf. 2009, 72, 1228-1233. [CrossRef]

21. TemaNord. Siloxanes in the Nordic Environment; Nordic Council of Ministers, TemaNord: Copenhagen, Denmark, $2005 ;$ p. 593.

22. Environment Canada. Data for Batch 2 Substances Collected under the Canadian Environmental Protection Act, 1999, Section 71: Notice with Respect to Certain Batch 2 Challenge Substances; Existing Substances Program: Toronto, ON, Canada, 2007.

23. CEPA (Canadian Environmental Protection Act). Statutes of Canada. Ottawa: Public Works and Government Services Canada. Canada Gazette. Part III. 1999, 22, Chapter 33. Available online: http:/ / canadagazette.gc.ca/partIII/1999/g3-02203.pdf (accessed on 16 March 2021).

24. Sanchís, J.; Llorca, M.; Picó, Y.; Farré, M.; Barceló, D. Volatile dimethylsiloxanes inmarket seafood and freshwater fish from the Xúquer River. Spain. Sci. Total Environ. 2016, 545-546, 236-243. [CrossRef] [PubMed]

25. Annelin, R.; Frye, C. The piscine bioconcentration characteristics of cyclic and linear oligomeric permethylsiloxanes. Sci. Total. Environ. 1989, 83, 1-11. [CrossRef]

26. Opperhuizen, A.; Damen, H.W.J.; Asyee, G.M.; Van der Steen, J.M.D. Uptake and Elimination by Fish of Polydime-thylsiloxanes (Silicones) after Dietary and Aqueous Exposure. Toxicol. Environ. Chem. 1987, 13, 265-285. [CrossRef]

27. Drottar, K.R. 14C-Dodecamethylcyclohexasiloxane (14C-D6): Bioconcentration in the Fathead Minnow (Pimphales promelas) under Flow-Through Test Conditions. HES Study No. 9882-102; Health and Environmental Sciences, Dow Corning Corporation: Auburg, MI, USA, 2005.

28. IUCLID. IUCLID Dataset for Dodecamethylcyclohexa siloxane; Epona Associates LLC.: Willington, CT, USA, 2005.

29. Berres, M.-L.; Trautwein, C.; Zaldivar, M.M.; Schmitz, P.; Pauels, K.; Lira, S.A.; Tacke, F.; Wasmuth, H.E. The chemokine scavenging receptor D6 limits acute toxic liver injury in vivo. Biol. Chem. 2009, 390, 1039-1045. [CrossRef]

30. Environment Canada. Draft Screening Assessment for Dodecamethylcyclohexasiloxane (CAS 540-97-6). Draft for Public Consultation, May 2008; Environment Canada and Health Canada: Ottawa, ON, Canada, 2008. Available online: https:/ / www.ec.gc.ca/eseees/FC0D11E7-DB34-41AA-B1B3-E66EFD8813F1/batch2_540-97-6_en.pdf (accessed on 16 March 2021).

31. Onnekink, C.; Kappel, R.M.; Boelens, W.C.; Pruijn, G.J.M. Low molecular weight silicones induce cell death in cultured cells. Sci. Rep. 2020, 10, 9558. [CrossRef] [PubMed]

32. Hossain, A.; Kujala, H.; Bland, L.M.; Burgman, M.; Lahoz-Monfort, J.J. Assessing the impacts of uncertainty in climate-change vulnerability assessments. Divers. Distrib. 2019, 25, 1234-1245. [CrossRef]

33. Schilderman, P.; Moonen, E.; Maas, L.; Welle, I.; Kleinjans, J. Use of Crayfish in Biomonitoring Studies of Environmental Pollution of the River Meuse. Ecotoxicol. Environ. Saf. 1999, 44, 241-252. [CrossRef]

34. Dhindsa, R.S.; Dhindsa, P.P.; Thorpe, T.A. Leaf senescence correlated with increased levels of membrane permeability and lipid-peroxidation and decreased levels of superoxide dismutase and catalase. J. Exp. Bot. 1980, 32, 93-101. [CrossRef]

35. Aebi, H. Catalase in vitro. Methods Enzymol. 1984, 105, 121-126.

36. Huang, W.; Bi, X.; Zhang, X.; Liao, X.; Hu, X.; Wu, J. Comparative study of enzymes, phenolics, carotenoids and color of apricot nectars treated by high hydrostatic pressure and high temperature short time. Innov. Food Sci. Emerg. Technol. 2013, 18, 74-82 [CrossRef]

37. Heath, R.L.; Packer, L. Photoperoxidation in isolated Chloroplasts of Fatty Acid Peroxidation chlorophyll. Arch. Biochem. Biophisics. 1968, 126, 189-198. [CrossRef]

38. Guo, T.R.; Zhang, G.P.; Zhang, Y.H. Physiological changes in barley plants under combined toxicity of aluminum, copper and cadmium. Colloids Surf. B Biointerfaces 2007, 57, 182-188. [CrossRef]

39. Han, D.; Xiong, S.; Tu, S.; Liu, J.; Chen, C. Interactive effects of selenium and arsenic on growth, antioxidant system, arsenic and selenium species of Nicotiana tabacum L. Environ. Exp. Bot. 2015, 117, 12-19. [CrossRef]

40. Huang, H.; Rizwan, M.; Li, M.; Song, F.; Zhou, S.; He, X.; Ding, R.; Dai, Z.; Yuan, M.; Cao, Y.; et al. Comparative efficacy of organic and inorganic silicon fertilisers on antioxidant response, $\mathrm{Cd} / \mathrm{Pb}$ accumulation and health risk assessment in wheat (Triticum aestivum L.). Environ. Pollut. 2019, 255 Pt 1, 113146. [CrossRef] [PubMed]

41. Thiel, T.; Michalek, W.; Varshney, R.; Graner, A. Exploiting EST databases for the development and characterisation of genederived SSR-markers in barley (Hordeum vulgare L.). Theor Appl Genet. 2003, 106, 411-422. [CrossRef] [PubMed]

42. Untergrasser, A.; Cutcutache, I.; Koressaar, T.; Ye, J.; Faircloth, B.C.; Remm, M.; Rozen, S.G. Primer3-New Capabilities and Interfaces. Nucl. Acids Res. 2012, 40, e115. Available online: http:/ / bioinfo.ut.ee/primer3 (accessed on 16 March 2021). [CrossRef] [PubMed]

43. Livak, K.J.; Schmittgen, T.D. Analysis of relative gene expression data using real time quantitative PCR and the 2(-Delta Delta $\mathrm{C}(\mathrm{T})$ ) method. Methods 2001, 25, 402-408. [CrossRef] [PubMed]

44. STAR (Statistical Tool for Agricultural Research). Biometrics and Breeding Informatics, PBGB Division, R-packages 1.5, version 2.0.1. 2014; International Rice Research Institute: Los Baños, Philippines, 2014.

45. Das, S.; Tseng, L.-C.; Chou, C.; Wang, L.; Souissi, S.; Hwang, J.-S. Effects of cadmium exposure on antioxidant enzymes and histological changes in the mud shrimp Austinogebia edulis (Crustacea: Decapoda). Environ. Sci. Pollut. Res. 2019, 26, 7752-7762. [CrossRef] 
46. Hossain, M.; Huang, H.; Yuan, Y.; Wan, T.; Jiang, C.; Dai, Z.; Xiong, S.; Cao, M.; Tu, S. Silicone stressed response of crayfish (Procambarus clarkii) in antioxidant enzyme activity and related gene expression. Environ. Pollut. 2021, 274, 115836. [CrossRef]

47. Soegianto, A.; Winarni, D.; Handayani, U.S. Hartati Bioaccumulation, Elimination, and Toxic Effect of Cadmium on Structure of Gills and Hepatopancreas of Freshwater Prawn Macrobrachium sintangese (De Man, 1898). Water Air Soil Pollut. 2013, $224,1-10$. [CrossRef]

48. Lin, Y.; Huang, J.-J.; Dahms, H.-U.; Zhen, J.-J.; Ying, X.-P. Cell damage and apoptosis in the hepatopancreas of Eriocheir sinensis induced by cadmium. Aquat. Toxicol. 2017, 190, 190-198. [CrossRef]

49. Pedrajas, J.R.; Gavilanes, F.; López-Barea, J.; Peinado, J. Incubation of superoxide dismutase with malondialdehyde and 4hydroxy-2-nonenal forms new active isoforms and adducts. An evaluation of xenobiotics in fish. Chem. Interactions 1998, 116, 1-17. [CrossRef]

50. Almroth, B.C.; Sturve, J.; Berglund, Å.; Förlin, L. Oxidative damage in eelpout (Zoarces viviparus), measured as protein carbonyls and TBARS, as biomarkers. Aquat. Toxicol. 2005, 73, 171-180. [CrossRef]

51. Livingstone, D.R. Contaminant-stimulated reactive oxygen species production and oxidative damage in aquatic organisms. Mar. Pollut. Bull. 2001, 42, 656-666. [CrossRef]

52. Dalle-Donne, I.; Rossi, R.; Giustarini, D.; Milzani, A.; Colombo, R. Protein carbonyl groups as biomarkers of oxidative stress. Clin. Chim. Acta 2003, 329, 23-38. [CrossRef]

53. Wei, K.; Yang, J. Oxidative damage of hepatopancreas induced by pollution depresses humoral immunity response in the freshwater crayfish Procambarus clarkii. Fish Shellfish. Immunol. 2015, 43, 510-519. [CrossRef]

54. Carvalho, C.S.; Bernusso, V.A.; Araujo, H.S.S.; Espíndola, E.L.G.; Fernandes, M.N. Biomarker responses as indication of contaminant effects in Oreochromis niloticus. Chemosphere 2012, 89, 60-69. [CrossRef] [PubMed]

55. Jin, Y.; Zheng, S.; Pu, Y.; Shu, L.; Sun, L.; Liu, W.; Fu, Z. Cypermethrin has the potential to induce hepatic oxidative stress, DNA damage and apoptosis in adult zebra fish (Danio rerio). Chemosphere 2011, 82, 398-404. [CrossRef] [PubMed]

56. Köprücü, K.; Yonar, S.M.; Şeker, E. Effects of cypermethrin on antioxidant status, oxidative stress biomarkers, behavior, and mortality in the freshwater mussel Unio elongatulus eucirrus. Fish. Sci. 2010, 76, 1007-1013. [CrossRef]

57. Barim-Oz, O.; Şahin, S. Oxidative stress and some biochemical parameters during starvation and refeeding in Astacus leptodactylus (Esch., 1823). Cell. Mol. Biol. 2016, 62, 35-43. [CrossRef]

58. Kovacevic, B.T.; Pavlovic, Z.S.; Borkovic, S.S.; Milosevic, M.S.; Kosanovic, K.; Stajn, S.A.; Petrovic, M.V.; Saicic, S.Z. Superoxide dismutase (SOD) and catalase (CAT) activities in some tissues of three freshwater crayfish species. Acta Physiol. Pharmacol. Serb. 2006, 42, 193-201.

59. Chen, Y.F.; Ai, C.X.; Lin, Q.W.; Xu, H.; Shen, Y.H. Effect of salinity stress on the activities of phenol oxidase and superoxide dismutase of the serum, tissue and organ of mud crab, Scylla serrata. J. Oceanogr. Taiwan Strait 2007, 26, 569-575.

60. Rameshthangam, P.; Ramasamy, P. Antioxidant and membrane bound enzymes activity in WSSV-infected Penaeus monodon Fabricius. Aquaculture 2006, 254, 32-39. [CrossRef]

61. Liu, Y.; Jang, X.L.; Lv, Q.; Guan, H.S. Effects of mannuronate polysaccharide on enzymes of Penaeus chinensis related with immune and hemolysis. J. Fish. China 2000, 24, 549e53.

62. Barim-Oz, O.; Yilmaz, S. Effects of dietary antioxidants on oxidative stress, antioxidant defence and growth of freshwater crayfish Astacus leptodactylus (Eschscholtz, 1823) during the reproductive period in females. Aquac. Res. 2016, 48, 2516-2527. [CrossRef]

63. Thomas, P.; Juedes, M.J. Influence of lead on glutathione status of Atlantic croaker tissues. Aquat. Toxicol. 1992, 23, 11-30. [CrossRef]

64. Sheader, D.L.; Williams, T.D.; Lyons, B.P.; Chipman, J.K. Oxidative stress response of European flounder (Platichthys flesus) to cadmium determined by acustom cDNA microarray. Mar. Environ. Res. 2006, 62, 33-44. [CrossRef]

65. Woo, S.; Yum, S.; Kim, D.-W.; Park, H.-S. Transcripts level responses in a marine medaka (Oryzias javanicus) exposed to organophosphorus pesticide. Comp. Biochem. Physiol. Part C Toxicol. Pharmacol. 2009, 149, 427-432. [CrossRef]

66. Craig, P.M.; Wood, C.M.; McClelland, G.B. Oxidative stress response and gene expression with acute copper exposure in zebra fish (Danio rerio). Am. J. Physiol.Regul. Integr. Compar. Physiol. 2007, 293, 1882-1892. [CrossRef]

67. Liu, Y.; Wang, J.S.; Wei, Y.H.; Zhang, H.X.; Xu, M.Q.; Dai, J.Y. Induction of time dependent oxidative stress and related transcriptional effects of perfluorododecanoic acid in zebra fish liver. Aquat. Toxicol. 2008, 89, 242-250. [CrossRef]

68. Circu, M.L.; Aw, T.Y. Reactive oxygen species, cellular redox systems, and apoptosis. Free. Radic. Biol. Med. 2010, 48, 749-762. [CrossRef] [PubMed]

69. Sun, M.; Li, Y.T.; Liu, Y.; Lee, S.C.; Wang, L. Transcriptome assembly and expression profiling of molecular responses to cadmium toxicity in hepatopancreas of the freshwater crab Sinopotamon henanense. Sci. Rep. 2016, 6, 19405. [CrossRef] [PubMed]

70. Zhang, Y.; Li, Z.; Kholodkevich, S.; Sharov, A.; Feng, Y.; Ren, N.; Sun, K. Cadmium-induced oxidative stress, histopathology, and transcriptome changes in the hepatopancreas of freshwater crayfish (Procambarus clarkii). Sci. Total. Environ. 2019, 666, 944-955. [CrossRef] [PubMed] 